\title{
THE INFLUENCE OF POLLEN VIABILITY ON SEED SET AND FRUIT MASS IN STRAWBERRY (FRAGARIA X ANANASSA DUCH.)
}

\author{
Elżbieta Kaczmarska, Agnieszka M. Dobrowolska, Jerzy A. Hortyński \\ University of Life Sciences in Lublin, \\ Department of Genetics and Horticultural Plant Breeding, Akademicka 15, 20-950 Lublin, Poland \\ e-mail: elzbieta.kaczmarska@ar.lublin.pl
}

Received: 17.09.2007

\section{S u m m a r y}

This research was conducted in 2006 in the Experimental Station of the Department of Genetics and Horticultural Plant Breeding in Felin near Lublin. It included 7 cultivars of strawberry ('Pastel', 'Salut', 'Teresa', 'Jota', 'Paula', 'Senga Sengana', 'Plena') and two selected clones: 2395 and 3995 that belonged to the Department.

Analysis of pollen fertility was carried out on the basis of materials collected on five occasions: on May 17 (at the beginning of florescence), May 20 and May 24 (the peak of florescence) and on June 2 and June 13 (the end of florescence). Smear preparations stained with $2 \%$ acetocarmin and glycerin solution $(1: 1)$ were used to test pollen viability.

The highest percent of viable pollen in 2006 was in cultivar 'Jota' (70.88\%). The lowest viability had pollen of 'Teresa' cultivar (33.83\%).

The average content of viable pollen grains was the lowest on May $20(36.79 \%)$. The highest pollen fertility was noted on June $2(62.15 \%)$, the percent of fertile pollen on a similar level was observed on May 17 and 24 and June13.

The cultivar 'Jota' was characterized by an increased level of pollen fertility that was quite high during the whole period of florescence.

The number of seeds has a great influence on the proper development of spurious strawberry fruit.

The mass of seeds from a single fruit has a great influence on the mass of fruits in both large and small fruit categories.

Pollen viability affected the mass of seeds on big fruits $(\mathrm{r}=0.444)$, but there is no clear direct relationship between pollen fertility and mass of strawberry fruit $(r=-0.193$ and $r=-0.052)$.

Key words: pollen viability, Fragria $x$ ananassa Duch., seed set, spurious fruit

\section{INTRODUCTION}

Poland is one of European and world leading strawberry producers. Due to very favourable weather conditions during fruit ripening season, fruits produced in Poland develop a distinctive taste and aroma which make them very popular on the international market (R e j m a n, 1994).

For years, cv. 'Senga Sengana' has been the most widely grown strawberry cultivar in Poland. In recent years, a growing interest in dessert cultivars like 'Dukat' or 'Elsanta' is observed. The mentioned cultivars make up $16 \%$ of commercial strawberry production. It was marketing reasons that mainly influenced the interest in dessert cultivars (Małodobry and Bieniasz, 1999).

Success in the modern strawberry industry largely depends on the cultivar used. Because of the growing interest in fresh fruit, it has become necessary to breed new cultivars characterized by resistance to low temperature, drought, diseases, pest as well as by good flavour and great yielding potential ( $\mathrm{K} \mathrm{a} \mathrm{c} \mathrm{z} \mathrm{m} \mathrm{a} \mathrm{r} \mathrm{s} \mathrm{k} \mathrm{a,} \mathrm{2000).}$

Many strawberry cultivars do not produce high yields in our climatic conditions or in the regions where they were developed. Thus, such cultivars are not recommended for field production. Yet, they may be used as valuable material for further breeding ( $\dot{Z}$ u r a w i c z, 1997).

This paper deals with the relation between the number and mass of seeds needed for the proper development of fruit and its mass. The influence of pollen fertility on this process is given special attention.

\section{MATERIALS AND METHODS}

The primary objective of the present research was to determine the quality of pollen and other utility traits. It was conducted in 2006 in the Experimental Station of the Department of Genetics and Horticultural Plant Breeding in Felin near Lublin. It included seven cultivars of strawberry ('Pastel', 'Salut', 'Teresa', 'Jota', 'Paula', 'Senga Sengana', 'Plena') and two selected clones: 2395 and 3995 that belonged to the Department. During fructification of those cultivars, ten fruits of each cultivar were picked randomly. Then, the following 
characteristics were examined: the number of seeds of a single fruit, the mass of seeds and the mass of a single fruit. The analysis was carried out for the category of large fruits (the mass of a fruit was above $5 \mathrm{~g}$ ) and small fruits (the mass of a fruit was below $5 \mathrm{~g}$ ).

Statistical analysis of the data included arithmetic means, standard deviation, variance and coefficient of variation $\mathrm{V}$ (at $\mathrm{p}=0.05$ confidence level).

The tests of pollen viability were made on five occasions: on May 7 (florescence onset), May 20 and 24 (the peak of florescence) and on June 2 and 13 (the end of florescence). Smear preparations stained with $2 \%$ acetocarmin and glycerin solution (1:1) were prepared. Fully coloured pollen was treated as viable, while uncoloured pollen was considered as non-viable. Correlations between the analyzed traits were estimated using the correlation coefficient (r).

\section{RESULTS}

In 2006 the highest percent of viable pollen was found in the clone 3995 in which $70.88 \%$ of seeds were fully filled with cytoplasm. Cv. 'Plena' showed the lowest viability; only $33.83 \%$ of its pollen was able to pollinate.
Comparing the average content of viable pollen grains collected at different dates, the lowest content was on May 20 (36.79\%), the highest on June 2 (62.15\%). On the other occasions (May 17 and 24 and June 13), the percentage of viable pollen grains remained similar.

When analysing the florescence stages (from May 17 to June 13) of different cultivars, a characteristic pattern of the pollen fertility curve was observed. The results presented in Table 1 show that in the case of cultivars 'Senga Sengana', 'Plena', 'Teresa' and 'Salut' pollen fertility in the initial period (May 17 and 20) is very low to reach its highest level around June 2 and it decreases again in the later period (June 13).

The cultivar 'Pastel' and clones 2395 and 3995 represented a different fertility curve than the one described above. It started from a very high value at the beginning of florescence (May 17), then decreased in the mid period (June 2) and rose again at the end of florescence (June 13). Only the cultivar 'Jota' demonstrated an increased pollen fertility level that was quite high during the whole period of florescence.

Table 2 shows the test results of pollen fertility and chosen traits of fruits for nine cultivars of strawberry.

There was a strong relationship between pollen fertility and other features for cv. 'Jota'. The average

Table 1

The content of fertile pollen tested between 17 May - 13 June 2006 in nine different cultivars (\%).

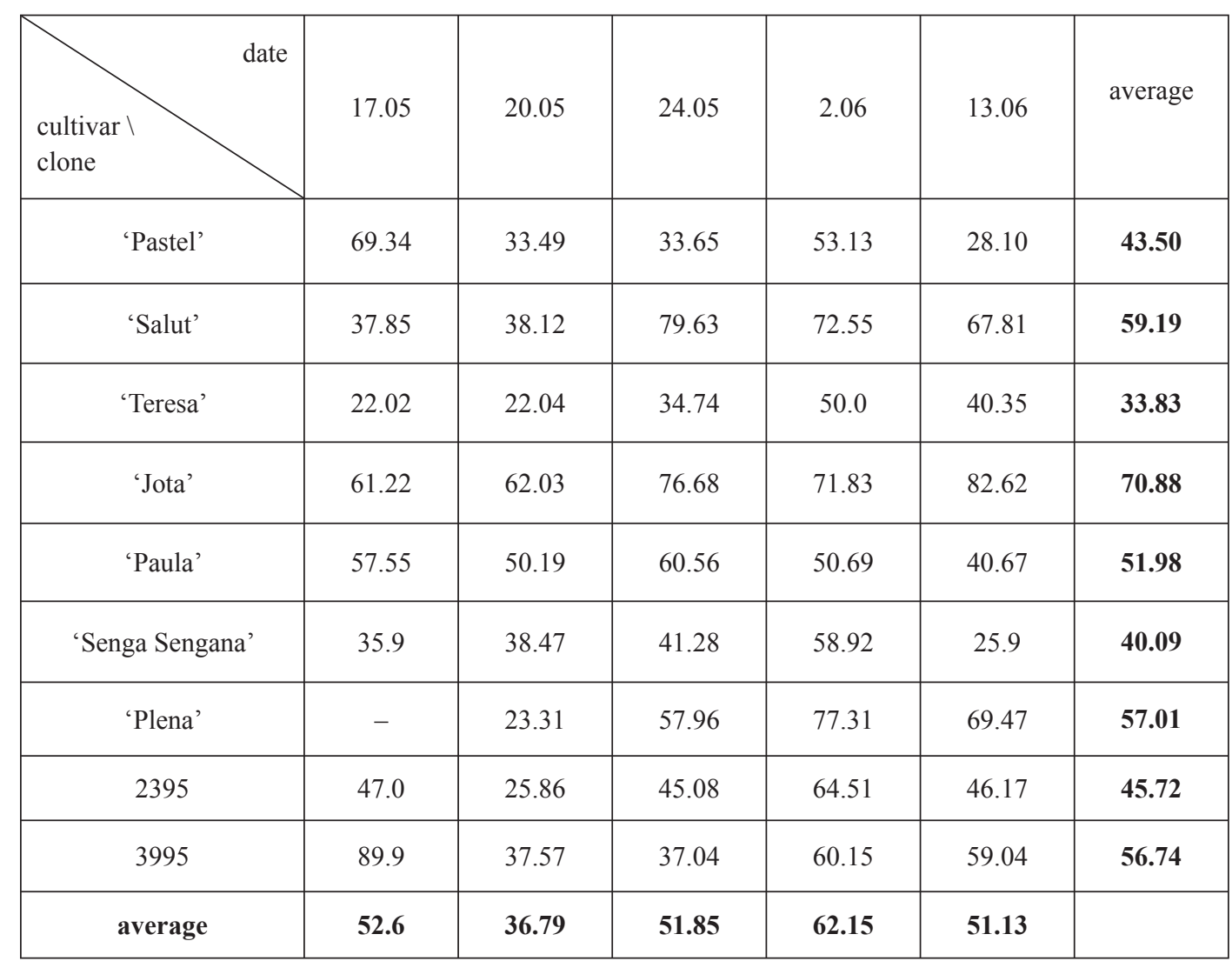


Table 2

Comparison of chosen traits for 9 strawberry genotypes.

\begin{tabular}{|c|c|c|c|c|}
\hline Cultivar & $\begin{array}{c}\text { average mass of } \\
\text { single fruit [g] }\end{array}$ & $\begin{array}{c}\text { average number } \\
\text { of seeds }\end{array}$ & $\begin{array}{c}\text { average mass } \\
\text { of seeds }[\mathrm{g}]\end{array}$ & $\begin{array}{c}\text { average pollen } \\
\text { fertility } \\
{[\%]}\end{array}$ \\
\hline 81 Pastel & $13.66^{*}$ & $251.9^{*}$ & $0.16^{*}$ & $43.50^{*}$ \\
\hline 81 Salut & $14.47^{*}$ & $315.73^{*}$ & $0.17^{*}$ & $59.19^{*}$ \\
\hline 81 Teresa & $13.78^{* *}$ & $276.95^{*}$ & $0.17^{*}$ & $33.83^{* *}$ \\
\hline 81 Jota & $16.42^{* *}$ & $377.7^{* *}$ & $0.26^{* *}$ & $70.88^{* *}$ \\
\hline 'Paula' & $13.18^{* *}$ & $236.2^{* *}$ & $0.18^{*}$ & $51.98^{* *}$ \\
\hline 'Senga Sengana' & $12.39^{*}$ & $370.15^{* *}$ & $0.23^{*}$ & $40.09^{*}$ \\
\hline 'Plena' & $11.4^{*}$ & $293.15^{*}$ & $0.14^{* *}$ & $57.01^{*}$ \\
\hline 812395 & $15.01^{* *}$ & $340.25^{*}$ & $0.20^{*}$ & $45.72^{*}$ \\
\hline 813995 & $9.38^{* *}$ & $286.55^{*}$ & $0.15^{*}$ & $56.74^{*}$ \\
\hline
\end{tabular}

* Values marked with different letters differ statistically at $\mathrm{p}=0.05$.

Table 3

Statistical parameters of chosen characteristics for strawberry large fruits.

\begin{tabular}{|l|c|c|c|c|}
\hline Parameter & $\begin{array}{c}\bar{x} \\
\text { average }\end{array}$ & $\begin{array}{c}\sigma^{2} \\
\text { variance }\end{array}$ & $\begin{array}{c}\sqrt{\sigma^{2}}=\sigma \\
\text { standard } \\
\text { deviation }\end{array}$ & $\begin{array}{c}(\mathrm{V}) \\
\text { coefficient of } \\
\text { variation }\end{array}$ \\
\hline Number of seeds from a single fruit & 392.956 & 5359.218 & 73.2067 & 0.1863 \\
\hline Mass of seeds from a single fruit $[\mathrm{g}]$ & 0.25 & 0.00383 & 0.0619 & 0.2466 \\
\hline Mass of a single fruit $[\mathrm{g}]$ & 20.95 & 12.6136 & 3.5516 & 0.1695 \\
\hline
\end{tabular}

Table 4

Correlation coefficient (r) of chosen characteristics for strawberry large fruits.

\begin{tabular}{|l|c|c|c|}
\hline Parameter & b & c & d \\
\hline Number of seeds from a single fruit (a) & 0.807 & 0.424 & 0.368 \\
\hline Mass of seeds from a single fruit [g] (b) & & 0.807 & 0.444 \\
\hline Mass of a single fruit [g] (c) & & & -0.193 \\
\hline Average pollen fertility (d) & & & \\
\hline
\end{tabular}


Table 5

Statistical parameters of chosen characteristics for strawberry small fruits.

\begin{tabular}{|c|c|c|c|c|}
\hline characteristic & $\begin{array}{c}\bar{x} \\
\text { average }\end{array}$ & $\begin{array}{c}\sigma^{2} \\
\text { variance }\end{array}$ & $\begin{array}{c}\sqrt{\sigma^{2}}=\sigma \\
\text { standard deviation }\end{array}$ & $\begin{array}{c}(\mathrm{V}) \\
\text { coefficient of } \\
\text { variation }\end{array}$ \\
\hline Number of seeds from a single fruit & 217.84 & 506.927 & 0.0173 & 0.1427 \\
\hline Mass of seeds from a single fruit $[\mathrm{g}]$ & 0.12 & 0.0003 & 0.36374 & 0.1034 \\
\hline Mass of a single fruit [g] & 5.66 & 0.2601 & 0.5100 & 0.0901 \\
\hline
\end{tabular}

Table 6

Correlation coefficient (r) of chosen characteristics for strawberry small fruits.

\begin{tabular}{|l|c|c|c|}
\hline characteristic & Parameter & b & c \\
\hline Number of seeds from a single fruit (a) & 0.217 & 0.164 & 0.201 \\
\hline Mass of seeds from a single fruit [g] (b) & & 0.634 & 0.065 \\
\hline Mass of a single fruit [g] (c) & & & -0.052 \\
\hline Average pollen fertility (d) & & & \\
\hline
\end{tabular}

content of pollen grains in the cultivar 'Jota' was high (70.88\%), the average mass of a single fruit was the heaviest of all the analyzed genotypes $(16.42 \mathrm{~g})$. The number of seeds in the fruit (377.7) and their mass $(0.26 \mathrm{~g})$ were higher than in other cultivars.

A similar relationship was observed for the cultivar 'Salut': with its pollen fertility at the level of $59.19 \%$, the mass of seeds was not that heavy $(0.17 \mathrm{~g})$, but the number of seeds and the mass of a single fruit (315.73 and $14.47 \mathrm{~g}$, respectively) were one of the highest and not much less than for the cultivar 'Jota'.

In contrast to clone 2395, the average mass of a single fruit $(15.01 \mathrm{~g})$ and the number of seeds $(340.25)$ were high despite of the fact that the average content of pollen grains was low $(45.72 \%)$.

Comparing the average numbers for the analyzed characteristics of all the tested genotypes, we can state that the number of seeds from a single fruit as well as their mass in the category of large fruits (the average mass of a fruit was $20.95 \mathrm{~g}$ ) was considerably higher compared to the corresponding numbers for small fruits (the average mass of a fruit was $5.66 \mathrm{~g}$ ) (Tab. 3 and 5). It should be emphasized that the coefficient of variation for the mass of a single fruit in the category of large fruits was the highest $(\mathrm{V}=0.2466)$. The lowest coefficient of variation concerns the mass of a single fruit in the category of small fruits $(\mathrm{V}=0.0901)$.

On the basis of the estimated correlation coefficient, a high correlation was found between the average number of seeds in a fruit and the average mass of seeds in the category of large fruits $(r=0.807)$. The mass of a single fruit in both the large and small fruit categories was evidently influenced by the number of seeds $(r=0.585$ in large fruit category, $r=0.634$ in small fruit category). Pollen viability had a beneficial effect on the mass of seeds in large fruits $(r=0.444)$. However, the direct relationship between pollen fertility and the mass of strawberry fruit cannot be confirmed (Tab. 4 and 6). 


\section{DISCUSSION}

The appropriate development of strawberry fruit, which in this case is a spurious fruit that formed from the growing receptacle, is to a large extent influenced by the number of seeds formed after pollination and fertilization of ovules. The size of the fruit depends mainly on the position of flowers in the capitulum - cyme. The growth of the receptacle is stimulated by hormonal substances that appear after fertilization of the ovules (S zczygi eł and P i erzga, 1999).

Studies of D e c (2006) have shown that the number of seeds from a single large fruit is sometimes even lower than from a small fruit. However, the research presented in this paper does not confirm it. In all the tested cultivars, the number of seeds from a large fruit was higher than from a small fruit. According to Dec, the mass of seeds from large fruits was almost always higher than of those from small fruits. This was also confirmed in our research. In our observations, it was proved for each of the tested cultivars and clones.

A study of pollen grains by Wy k a (1984) shows a slight difference in strawberry pollen viability. The content of pollen that were coloured (which meant it was viable) varied from 72 up to $98 \%$.

Ż e brow s ka and Hortyńs ki (1992) tested viability of fresh pollen of field plants. In their experiment, pollen of 'Teresa' and 'Senga Sengana' cultivars was coloured in $65 \%$ and $49 \%$, respectively. In our research conducted in May and June 2006, the percentage for these cultivars was lower ('Teresa'-33.83\%, Senga Sengana' - 40.09\%).

According to $\mathrm{Kaczmarska}$ (2000), pollen fertility of 'Senga Sengana' in the fourth week of May was $15 \%$. In the present research, pollen fertility was checked 5 times, and the lowest level for this cultivar was $25.9 \%$ and the highest $40 \%$. It was similar in the case of cultivar 'Teresa'.

The differences found in our research prove the opinion of many authors concerning an enormous impact of weather conditions, especially temperature and rainfall, on blooming and consequently on the setting and development of fruit of strawberry grown in field conditions (Hortyński and Hulewicz, 1992; Żebrowska and Hortyński, 1992; Kostus i a k, 2001).

The following conclusion may be drawn from our findings :

1. In 2006 the highest content of viable pollen $(70.88 \%)$ was observed in 'Jota' cultivar 3995, and the lowest $(33.83 \%)$ in 'Teresa' cultivar.

2. 'Jota' cultivar is characterized by having a great influence of pollen quality on the number and mass of seeds and also on the average mass of a single fruit.

3. There was a strong relationship between the number of seeds and the average mass of strawberry fruit. It was statistically proved in the category of large fruits in which the average mass of a fruit is $20.95 \mathrm{~g}$.

4. Correlation coefficient data reveal a strong relationship between the mass of seeds and the mass of fruit in both categories $(r=0.585$ for big fruits, $r=0.634$ for small fruits).

5. Analysis of the correlation coefficient shows a quite strong relationship between pollen fertility and the mass of seeds on large fruits $(r=0.444)$.

6. No correlation between pollen viability and the mass of strawberry fruit was found, the correlation coefficient for large fruits was -0.193 and for small fruits -0.052 .

\section{REFERENCES}

Dec. A. A., 2006. Relationship between mass of a single strawberry fruit (Fragaria x ananassa Duch.) and number of its' seeds. Diss. Agricultural University of Lublin.: 1-78.

Hortyński J., Hulewicz T., 1992. Relationship between crop and size of strawberry fruit and climatic conditions in field growing" 1st International Strawberry Seminar, Lublin: 89 -95.

K a c z m a r s k a E., 2000. Genetic analysis of strawberry photoperiodic sensitivity" (Fragaria x ananassa Duch.)." Diss. Agricultural University of Lublin: 1-113.

Kaczmarska E., 2003. Pollen viability and seed formation in selected strawberry cultivars (Fragaria x ananassa Duch.). Acta Sci. Polonorum. Hortorum Cultus. 2 (1): 111-116.

Małodobry M., Bieniasz M., 1999. Assessment of nine different strawberry cultivar yielding. Science Jurnal AR Kraków, Scence Session: 325-328.

Rejman A., 1994. Pomology i variantology of orchard plants. PWRiL, Warsaw: 603-620.

Szczygieł A., Pierzga K., 1999. Strawberry. Hortpress, Warszawa: 8-12.

Wyka P. 1984. Trails of restoring pollen fertility in sterile bigenes considering Frgaria kind. Diss. SGGW Warsaw: 1-90.

Żebrowska J., Hortyński J. A., 1992. Storaging and pollen viability in selected strawberry cultivar. (Fragaria $x$ ananassa Duch.). II Polish Garden Plants Growers Meeting. AR Lublin: 333-336.

Żurawicz E., 1997. Strawberry and wild strawberry. PWRiL, Warsaw: 5-27.

\section{Wpływ żywotności pyłku na osadzenie nasion i masę owoców truskawki (Fragaria $x$ ananassa Duch.)}

\section{Streszczenie}

Badania dotyczące jakości pyłku oraz wybranych cech użytkowych owoców truskawki prowadzono w roku 2006 na plantacji doświadczalnej Katedry Genetyki i Hodowli Roślin Ogrodniczych w GD Felin k. Lublina. Obejmowały one siedem odmian truskawki ('Pastel', 'Salut', 'Teresa', 'Jota', 'Paula', 'Senga Sengana', 'Plena') i dwa 
wyselekcjonowane klony: 2395 oraz 3995, znajdujące się w kolekcji KGiHRO.

Badania żywotności pyłku przeprowadzono w oparciu o materiał pobrany w czterech terminach: 17 $\mathrm{V}$ (na początku kwitnienia), 20 i $24 \mathrm{~V}$ (w pełni kwitnienia) oraz 2 i 13 VI (pod koniec kwitnienia). Wykonano preparaty rozmazowe barwione $2 \%$ roztworem acetokarminu z gliceryną (1:1).

Największy procent żywotnego pyłku stwierdzono u odmiany 'Jota' $(70,88 \%)$, natomiast najniższą żywotność miał pyłek odmiany 'Teresa' (33,83\%).

Średnia zawartość żywotnych ziaren pyłku była najniższa 20 maja i wynosiła 36,79\%. Największą płodność uzyskał pyłek 2 VI $(62,15 \%)$, w pozostałych trzech terminach (17 i 24 maja oraz 13 czerwca) procent płodnego pyłku utrzymywał się na zbliżonym poziomie.

W przypadku odmiany 'Jota' płodność pyłku utrzymywała się na wysokim poziomie w ciagu całego okresu kwitnienia.

$\mathrm{Na}$ podstawie analizy statystycznej wyników zbadano zależności między płodnością pyłku a liczbą orzeszków z pojedynczego owocu, masą orzeszków na owocu, oraz masą pojedynczego owocu. Moc związku między badanymi cechami oszacowano za pomocą współczynnika korelacji.

Porównując średnie wartości analizowanych cech dla wszystkich badanych genotypów stwierdzono, że zarówno liczba orzeszków z pojedynczego owocu jak również ich masa w grupie owoców dużych znacznie przewyższają analogiczne wartości oszacowane dla owoców małych. Masa orzeszków z pojedynczego owocu w sposób wyraźny wpływa na masę owoców obu kategorii, tj. owoców dużych i małych.

Żywotność pyłku miała pozytywny wpływ na masę orzeszków na owocach dużych (współczynnik korelacji $r=0,444$ ), natomiast nie stwierdzono bezpośredniej zależności między płodnością pyłku a masą owoców truskawki (współczynniki korelacji odpowiednio dla owoców dużych i małych, $r=-0,193$ i $r=-0,052)$. 